\title{
The Theme of the Issue: Migrant Localities, Ethnicity and Social Design: Some Results of the Regular Conference "The Specificity of Ethnic Migration Processes in Central Siberia in the $20^{\text {th }}-21^{\text {st }}$ Centuries: Experience and Prospects" (Krasnoyarsk, Siberian Federal University)
}

\author{
Viktor I. Dyatlov ${ }^{\mathrm{a}, \mathrm{b}}$ and Natalia P. Koptseva ${ }^{\mathrm{c} *}$ \\ ${ }^{a}$ Irkutsk State University \\ 1 Karl Marx Str., Irkutsk, 664003, Russia \\ ${ }^{b}$ National Research Tomsk State University \\ 34, Lenina, Tomsk, 634050, Russia \\ 'Siberian Federal University \\ 79 Svobodny, Krasnoyarsk, 660041, Russia
}

Received 18.10.2018, received in revised form 24.10.2018, accepted 07.11.2018

This is an introductory article to the issue of the Journal, which was compiled basing on the results of the regular Scientific and Practical Conference devoted to the ethnic and migration processes in Siberia. Siberian Federal University has been holding this Conference for over ten years. The issue is devoted to the topic of migrant localities, networks and informal practices in Siberian cities, the role of the migration groups in the design of social reality. The format of the thematic issue of the Journal contributes to the co-existence and conflict interaction of different and even alternative points of view, methodological approaches, provides an opportunity for internal implicit and even explicit discussions. Therefore, the authors bear the responsibility for their own articles, and the editors are only responsible for the quality and the organization of an opportunity to compare them.

Keywords: migrant localities, networks and practices, ethnicity, social design, Siberian Federal University, Conference.

The article is partially written within the framework of the project supported by the grant No. 18-18-00293 of Russian Research Foundation.

Research area: history, sociology.

Citation: Dyatlov, V.I., Koptseva N.P. (2018) The Theme of the Issue: Migrant Localities, Ethnicity and Social Design: Some Results of the Regular Conference "The Specificity of Ethnic Migration Processes in Central Siberia in the $20^{\text {th }}-21^{\text {st }}$ Centuries: Experience and Prospects"

(c) Siberian Federal University. All rights reserved

* Corresponding author E-mail address: vikdyatlov@yandex.ru; decanka@mail.ru

This work is licensed under a Creative Commons Attribution-NonCommercial 4.0 International License (CC BY-NC 4.0). 
(Krasnoyarsk, Siberian Federal University). J. Sib. Fed. Univ. Humanit. soc. sci., 11(11), 1732-1740. DOI: 10.17516/1997-1370-0347.

As we can see from the title of the text, this issue of the Journal is devoted to the presentation of some results of the regular Conference on the ethnic and migration processes in Siberia. It has been held for many years in Krasnoyarsk on the initiative and on the basis of Siberian Federal University. The theme of the Conference itself is extremely important and urgent for understanding of the mechanisms and dynamics of establishment and development of the Siberian migration society. It has predetermined the multidisciplinary character of discussions, the breadth of topics and fierce argumentation of the issues being discussed. There is no need to mention the topicality of the theme in the conditions of globalization of migration processes and their transformation into the key factor of world development, the foremost challenge for the whole humanity.

If we take the Siberian migration society, it was formed directly as a result of powerful migration processes and it is not able to exist and develop normally beyond this context. There is a close inseparable connection between the migration processes and the dynamics of establishment of the unified, though extremely diverse in cultural and ethnic sense, Siberian society. Peasants and city people, representatives of various classes, confessions and ethnic groups came and settled in Siberia. They interacted and integrated with similarly diverse and migrationally flexible aboriginal population. The experience of studying the migration and ethnic processes and interactions, which has been accumulated here, has global meaning and brings this problem beyond the local regional history: with all due respect to this genre.

The complexity and diversity of the migration and ethnic processes require interdisciplinary approaches to their study. As the Siberian society is non-uniform, including the regional level as well, great variety of forms and practices of migration strategies, mechanisms of mutual adjustment of newcomers, settled and aboriginal population inevitably lead to the idea that these processes should be studied not so much from the position and using the instruments of various scientific fields, but through mobilization of efforts of local expert communities. One of the instruments of this strategy could and should be regional scientific events of various format devoted to this topic: from conferences with a wide range of topics and a variable composition to narrow project workshops. It would be also great if such events were held regularly. Their results should be introduced in the broad scientific community by means of 
various publications: from collections of abstracts and materials to series of articles in journals and thematic collections.

This issue of the Journal, as it was previously outlined, is one of the results of such a conference. Therefore, the editors of the Journal decided that the introductory article would tell about the history of the Conference, its strategy and results obtained. This would contribute to a better understanding of the criteria of selection, logic of formation and structure of the issue. The next section of the article will be devoted to justification of the above.

"The specificity of ethnic migration processes in Central Siberia in the $20^{\text {th }}-21^{\text {st }}$ centuries: experience and prospects" Conference has been held for almost 10 years. It started in 2010 when the staff members and students of the Department of Cultural Studies of Siberian Federal University initiated the research of traditional cultures of small-numbered indigenous peoples of the North. In summer 2010, the first three expeditions were organized to the north of the Krasnoyarsk Krai and its western part as well. During the field works, a lot of interesting material was collected. It was decided to present it to the academic society in shortest terms in order not to lose its relevance. The third Russian Cultural Congress held in Saint Petersburg in the autumn of the same year was chosen as the place for presentation of the materials. The Congress gathered researchers in the field of cultural studies from all the country and was really a large-scale event, where it was easy for specific trends to stay unnoticed. At the end of participation in the Congress it became obvious that there is a necessity for holding a separate scientific event, which would be more local and deeper in its content, and more targeted as well: for those who were truly interested in the problems of ethnicity, ethnic groups, Siberia and migration.

In November 2011 the first Scientific and Practical Conference "The specificity of ethnic migration processes in Central Siberia in the $20^{\text {th }}-21^{\text {st }}$ centuries: experience and prospects" took place in Siberian Federal University. The Conference was held for one day only and its participants included lecturers, $\mathrm{PhD}$ students and undergraduate students of the University, who got an opportunity to discuss topical issues - peculiarities of the migration legislation, specificity of reception of some ethnic groups by a large society, difficulties of preserving traditional cultures in the conditions of globalization. It is noteworthy that the Conference from its very first year has become the place for presentation of the findings of not only successful specialists, but students as well. It was a breakaway from the common practice when scientific events are frequently divided into 'real' ones for researchers and 'pilot' ones for students, thus stratifying 
the participants and not giving the youth an opportunity to move to the professional level. "The specificity of ethnic migration processes in Central Siberia in the $20^{\text {th }}-21^{\text {st }}$ centuries: experience and prospects" Conference has become a discussion platform providing an opportunity for students to make their first steps in big science and be heard by the scientific society as equals. The topicality of the topics presented for discussion, a fresh look at the existing problems, active discussion of raised questions resulted in the situation that the authors of the reports presented at the Conference in November 2011 began to receive proposals to present their reports in terms of other scientific events, including those held by the executive authorities of the Krasnoyarsk Krai. Thus, an interuniversity conference from its first and only one day has declared its importance at the regional level.

In subsequent years, from 2012 to 2016, it was no longer possible to fit all the reports in one day, even by dividing them into separate sections. In addition, the practical component of the Conference was strengthened by discussion platforms organized by the migration service. It is noteworthy that over eight years the wellchosen name of the Conference has never changed, only its status has been adjusted: since 2017, the Conference has become an international scientific conference, which does not mean though that practical application stands apart from academic discussions. On the contrary, the basic research presented at the Conference has been more often tested quite successfully in real conditions of interethnic interactions in 2017-2018. One of the bright examples is the creation of the "Ethnic lesson" project presented and supported even at the federal level. Eventually, the Conference has started to gather more and more of those people who are directly connected with ensuring the most effective interethnic communication, which allows having some feedback.

One of the most popular (and that is also most topical) trends of research presented at "The specificity of ethnic migration processes in Central Siberia in the $20^{\text {th }}-21^{\text {st }}$ centuries: experience and prospects" Conference are:

- history of ethnic migration processes on the territory of Central Siberia;

- formation of identities: ethnic, cultural, linguacultural, etc.;

- peculiarities of working migration, including the organization of sociocultural adaptation and integration of working migrants;

- education of migrant children (including repatriating children) and receiving of relevant qualifications by the teachers;

- linguistic problems connected with migration processes; 
- problems related to the indigenous peoples of the territories and the necessity to adjust to newcomers (here a special place is occupied by the specificity of reaction of the representatives of small-numbered indigenous peoples on various migration waves, which come to the territories of traditional residence of the small-numbered indigenous peoples of the North);

- potential conflictogenity of migration processes and its control;

- analysis of the image of "another", "alien" in creative works and the role of art in the interethnic interaction in general.

Notwithstanding the geographic and time localization declared in the name of the Conference, most reports are connected with the specificity of historical ethnic migration processes, as well as modern ones, which are happening beyond the territory of Central Siberia: in Khakassia, Novosibirsk and Irkutsk regions, Kazakhstan, Portugal, Australia and other world regions. It is no coincidence that there is such a vast coverage of territories, while in terms of globalization there is no country, which is not connected with other states, the life of which would go in accordance with its own laws in total isolation. The study of the ethnic migration processes all over the world allows extrapolating most interesting conclusions, effective behavioural patterns on the situation in Central Siberia.

During the eight years of its existence "The specificity of ethnic migration processes in Central Siberia in the $20^{\text {th }}-21^{\text {st }}$ centuries: experience and prospects" Conference has been developing its form and deepening the contents. The results of the Conference held in 2018 allow to speak about the classical structure, which includes a plenary session with the reports on their latest research presented by the leading Russian and foreign researchers (recently they include D.G. Korovushkin, V.I. Dyatlov, N.P. Koptseva, E.A. Mikhailova, D.G. Grigorova, M.E. Schmaltz, V.L. Shunikov and others); the work of the sections in the most important trends (in 2018 they include pedagogical models of teaching Russian as a foreign language, sociocultural adaptation and integration of migrants as a factor of modern ethnic mobility, etc.; round table discussions on topical problems of preserving traditional cultures of the indigenous peoples of the North; public lectures of the leading Russian and foreign researchers; discussion platforms on the problems of adaptation and integration of migrants. An important integral part of "The specificity of ethnic migration processes in Central Siberia in the $20^{\text {th }}-21^{\text {st }}$ centuries: experience and prospects" Conference has become the presentation of the most outstanding publications in the field: monographs, scientific journals, collections of scientific abstracts, etc. Thus, the exchange of thoughts happens not only among the 
direct participants and is not limited by the procedure of the Conference, but is also disseminated both in territory and in time.

With time, though "The specificity of ethnic migration processes in Central Siberia in the $20^{\text {th }}-21^{\text {st }}$ centuries: experience and prospects" Conference is getting better and better organized, its continuing friendliness and even warm-heartedness is felt both by frequent and new participants, outstanding researchers and students. For students, the Conference is still a good platform for presenting their first studies, since, on the one hand, it is held within the walls of the University, which contributes to the familiarity of the environment and the feeling of support, but on the other hand, leading national and international researchers bring the discussion of students' findings to a higher level. The face of the Conference is getting more and more recognizable, and this is not only due to the high quality of scientific reports, the sharpness of discussions and the relevance of the issues raised. The officially adopted style - colours, fonts in which the printed products are made - has contributed to it greatly. The emblem and the name of the Conference are recognizable. They have become the sign of the quality of the scientific event, the participants of which annually encounter the only difficulty: how to choose between parallel sections, how to be at several places at once in order not to miss the important information.

The materials of the Conference have been published, though reports and discussions have shown that further detailed and concentrated work on many stated problems is possible and even necessary. One of such possibilities was fulfilled thanks to the proposal of the Journal to compile this special thematic issue.

The variety of themes and subjects, which are natural and necessary for a large conference on migration and ethnic issues, however, has posed a difficult problem of choosing a cross-cutting, organizing theme. Without this, we would have a mechanical set of separate, albeit qualitative, texts that are not interconnected. This would also be a good result for the Journal and the authors of the articles, but it would not give the cumulative effect that the concentration of the texts around a common problem or theme could provide.

It should be especially emphasized that the thematic issue of the Journal compiled after the Conference is not a collection of articles related to the problem and, certainly, is not a monograph. In addition to the cross-cutting theme, there should be a common idea, a common concept and a collective responsibility of the authors for the entire text created. The Conference, by definition, is a platform for discussions, clashes of methodological and even ideological approaches. Therefore, the thematic issue of the Journal necessarily provides for the possibility of coexistence and conflict interaction 
of non-coincident, and even alternative points of view, methodological approaches, the possibility of internal implicit and even explicit discussions. The authors are responsible only for their own texts, and the editors are responsible for their quality and the organization of an opportunity for their comparison. The editors consider this approach to be not a disadvantage, but an advantage of the chosen format.

The editors have chosen the organizing idea of the issue to be the topical problem for Russian research, i.e. the problem of interaction and interinfluence of ethnic and migration origins in the migration processes. In more detail, it is the problem of migrant localities in the urban space, especially the ideas of the city people about the existence of such localities, the form of their presentation, the description and estimation of such localities in categories and images. This problem is touched upon in the articles by I. Peshkov, K.V. Grigorichev and D.O. Timoshkin in the first section of the issue.

This is also closely connected with the problem of development and functioning of the migrant practices and networks in the urban space, their role in regulating everyday life, organization of work activities, relationships inside the migrant communities and relations with the host community. The articles by Yu.V. Elokhina, A.A. Voloshin and Yu.I. Koreshkova considering the problem through individual bright cases have constituted the second section.

The third section of the issue is devoted to the problem of social design, which is extremely important and urgent in the studies of the migration issues. In a way, the process of migration is a project. Migrant groups and societies, especially diasporal ones, can become and often become an integral part of the national construction projects. These projects are often presented in ethnic categories and images. The economic planning and the engineering approach to the development of strategies of economic development of Siberia in the Soviet times gave absolutely unexpected and surprising migration effects. The articles by V.I. Dyatlov and M.N. Baldano, V.P. Krivonogov and E.S. Ermilova, S.V. Lourie and R. Rezvanov are devoted to this problem.

Consideration of the ethnic and migration problems through the prism of social design gives considerable heuristic possibilities, but it is also accompanied by additional risks. Sometimes the collision of "the fish and the ichthyologist", which is typical for the researchers of sociopolitical processes, is particularly acute, the risk of moving from the study of projects to their design. There is a considerable risk to quietly cross the already loose and floating boundary between science and ideology. However, such an experience in case of special reflection, can be very useful. 
To conclude, let us note that the Conference is now standing firmly on its feet. It has gathered a significant group of regular participants. As it has gained authority and its popularity has increased, more and more new researchers are joining it, both those who have grown up (thanks to their participation in the Conference as well) in the region, and guests from other cities and countries. They bring new ideas, approaches and new layers of narration with them. This thematic issue of the Journal, if it of course finds a response from the reader, can become a pilot project, a permanent form of publishing the results of the Conference, another mechanism for the interaction of its participants.

\title{
Тема номера. Мигрантские локальности, этничность и социальное проектирование: некоторые результаты регулярных конференций «Специфика этнических миграционных процессов на территории Центральной Сибири в XX-XXI веках: опыт и перспективы»
} (Красноярск, Сибирский федеральный университет)

\author{
В.И. Дятлов ${ }^{\mathrm{a}, \boldsymbol{0}}$, Н.П. Копцева ${ }^{\mathrm{B}}$ \\ ${ }^{a}$ Иркутский государственный университет \\ Россия, 664003, Иркутск, ул. Карла Маркса, 1 \\ ${ }^{6}$ Национальный исследовательский \\ Томский государственный университет \\ Россия, 634050, Томск, пр. Ленина, 34 \\ ${ }^{6}$ Сибирский федеральный университет \\ Россия, 660041, Красноярск, пр. Свободный, 79
}

\begin{abstract}
Это вводная статья к проблемно-тематическому номеру журнала, сформированному по результатам регулярной научно-практической конференции, посвященной этномиграционному развитию Сибири. Конференция уже более десяти лет проводится Сибирским федеральным университетом. Тема номера-мигрантские локальности, сети и неформальные практики в сибирских городах, роль миграционного фактора в проектировании сочиальной реальности. Формат проблемно-тематического номера журнала предполагает возможность сосуществования и конфликтного взаимодействия несовпадаюших, а то и альтернативных точек зрения, методологических подходов, возможность внутренних имплицитных, а то и эксплицитных дискуссий. Авторы отвечают только за собственные тексты, а редакторы - за их качество и организацию возможности их сопоставления.
\end{abstract}

Ключевые слова: мигрантские локальности, сети и практики, этничность, сочиальное проектирование, Сибирский федеральный университет, конференции. 
Статья частично выполнена в рамках проекта, поддержанного грантом Российского научного фонда № 18-18-00293.

Научная спечиальность: 07.00.00 - исторические науки; 22.00.00 - сочиологические науки. 